\title{
Pengaruh Growth Opportunity dan Leverage pada Earning Response Coefficient
}

\section{Gusti Ayu Ary Amalia Tamara1 Fakultas Ekonomi dan Bisnis Universitas Udayana, Indonesia Email: amaliatamara@hotmail.com}

\author{
I Gusti Ngurah Agung Suaryana ${ }^{2}$ \\ Fakultas Ekonomi dan Bisnis \\ Universitas Udayana, Indonesia
}

\begin{abstract}
ABSTRAK
Penelitian ini bertujuan untuk memperoleh bukti empiris mengenai pengaruh growth opportunity serta leverage pada earning response coefficient (ERC). Penelitian ini dilakukan pada perusahaan perusahaan manufaktur yang terdaftar di Bursa Efek Indonesia periode 2016-2018. Metode penentuan sampel yang digunakan adalah dengan purposive sampling. Jumlah sampel terpilih adalah sebanyak 65 perusahaan. Teknik analisis data yang digunakan dalam penelitian ini adalah regresi linier berganda. Berdasarkan hasil penelitian, diketahui bahwa growth opportunity berpengaruh positif pada ERC. Sedangkan leverage yang pengaruh negatif pada ERC. Semakin tinggi tingkat pertumbuhan perusahaanakan meningkatkan ERC perusahaan. Sedangkan semakin tinggi leverage perusahaan akan menurunkan ERC.
\end{abstract}

Kata Kunci: Growth Opportunity; Leverage; Earning Response Coefficient.

\section{The Effect of Growth Opportunity and Leverage on Earning Response Coefficient}

\section{ABSTRACT}

The purpose of this research is aim to obtain empirical evidence about the effect of growth opportunity and leverage on earning response coefficient (ERC). This research was conducted at manufacturing companies listed on the Indonesia Stock Exchange in 2016-2018. The sample are selected with purposive sampling method. The number of selected sample are 65 companies. The analysis technique of this research is using multiple linear regression. The result showed that growth opportunity had positive effect on ERC. Whereas leverage had negative effect on ERC. The higher the company's growth rate will increase ERC. While the higher the leverage the company will reduce ERC.

Keywords: $\quad$ Growth Opportunity; Leverage; Earning Response Coefficient.

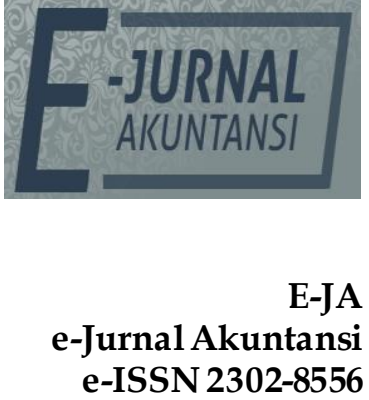

Vol. 30 No. 6

Denpasar, Juni 2020

Hal.1414-1424

Artikel Masuk:

27 Januari 2020

Tanggal Diterima:

13 Maret 2020

This Article is Avalilable in: https://ojs.unud.ac.id/index.php/Akuntansi/index 


\section{PENDAHULUAN}

Laporan keuangan adalah bentuk pertanggungjawaban pihak manajemen perusahaan yang berisikan informasi terkait keuangan perusahaan serta nantinya digunakan oleh pihak yang berkepentingan dalam mengambil keputusan (Radchobeh et al., 2012). Dalam laporan keuangan, terkandung berbagai informasi yang nantinya digunakan dalam pengambilan keputusan oleh investor. Dalam menentukan keputusan menjual atau membeli saham, investor memerlukan informasi salah satunya informasi mengenai laba perusahaan yang diperoleh melalui laporan keuangan (Maharani, 2014).

Moradi et al. (2010) menyatakan Investor memiliki perbedaan reaksi terhadap masing-masing laporan laba perusahaan. Informasi laba merupakan salah satu faktor terpenting dalam menilai kinerja serta merupakan informasi dasar bagi investor dalam melakukan penaksiran laba. Suaryana (2008) menyatakan pemakaian laba akuntansi dalam memberikan penilaian pada perusahaan dapat dianalisis melalui hubungan laba akuntansi dengan return. Laba dapat disebut memiliki kandungan informasi apabila laba berpengaruh pada return. Tingkat informasi laba juga dapat digunakan dalam mengukur seberapa jauh perubahan harga saham mengikuti publikasi infomasi laba (Syariffuloh \& Wahyudin, 2016).

Tabel 1. Pergerakan Harga Saham Perusahaan Manufaktur

\begin{tabular}{lllllll}
\hline Kode Emiten & Tanggal Publikas & $\mathrm{t}-2$ & $\mathrm{t}-1$ & $\mathrm{t} 0$ & $\mathrm{t}+1$ & $\mathrm{t}+2$ \\
\hline UNVR & 23 April 2019 & 49.400 & 48.275 & 49.250 & 48.500 & 46.400 \\
MYOR & 30 April 2019 & 2.590 & 2.590 & 2.600 & 2.610 & 2.630 \\
INTP & 30 April 2019 & 21.375 & 21.450 & 22.000 & 21.150 & 20.300 \\
\hline
\end{tabular}

Sumber: Data Penelitian, 2019

Berdasarkan Tabel 1. terdapat perbedaan pergerakan harga saham pada sekitar event window pada tiap emiten. Dalam laporan keuangan tahun 2018, laba bersih PT Unilever Indonesia Tbk. mengalami peningkatan sebesar 30,1\% dibanding periode yang sama pada tahun sebelumnya. Sedangkan PT Mayora Indah Tbk. memperoleh laba bersih yang meningkat sebesar $8 \%$ dibanding periode yang sama tahun sebelumnya. Namun disisi lain, PT Indocement Tunggal Perkasa Tbk. mengalami penurunan laba bersih sebesar 38,3\% selama tahun 2018. Hal tersebut mengindikasi bahwa terdapat perbedaan respon investor terhadap informasi laba yang dilaporkan oleh perusahaan

Teori sinyal berkaitan dengan adanya asimetri informasi dalam perusahaan. Perusahaan melaporkan informasi mengenai perusahaan kepada publik guna tidak terjadi asimetri informasi antara pihak internal dan eksternal perusahaan. Infomasi laba termasuk dalam informasi positif karena dengan adanya laba perusahaan maka secara langsung dapat meningkatkan nilai perusahaan dalam pasar modal. Informasi keuangan khususnya laba dapat meningkatkan minat investor dalam melakukan keputusan investasi dalam perusahaan (Ball \& Brown, 1968). Li (2014) menyatakan kualitas laba merupakan indikator yang penting dalam akurasi dalam melakukan evaluasi terhadap nilai perusahaan. Sehingga manajemen dituntut memberikan informasi laba yang relevan bagi pengguna informasi. Dampak yang kuat dalam pengumuman laba perusahaan pada harga saham akan memungkinkan investor dalam memiliki kepercayaan terhadap laporan keuangan (Al-Baidhani et al., 2017). Informasi laba 
yang relevan mengindikasi kualitas laba perusahaan yang baik. Laba perusahaan dikatakan berkualitas apabila tingkat laba yang dihasilkan perusahaan mengalami kenaikan (Hejazi, et al., 2012). Dechow et al. (2010) menyatakan reaksi pasar dalam merespon informasi laba perusahaan dapat diukur dengan Earning Response Coefficien (ERC).

ERC merupakan respon terhadap laba yang dipublikasikan oleh perusahaan (Rahayu \& Suaryana, 2015). ERC merepresentasikan reaksi pasar terhadap informasi laba yang dipublikasikan dan dilihat melalui pergerakan harga saham sejak tanggal publikasi laporan keuangan. ERC merupakan ukuran yang dapat digunakan untuk mengetahui seberapa besar reaksi pasar yang ditimbulkan dari informasi laba yang dipublikasi (Homan, 2018). Harga saham akan merepresentasikan return yang diperoleh dari saham (Mashayekhi \& Aghel, 2016). ERC diukur dengan menggunakan koefisien regresi slope abnormal return saham dan unexpected earning (Arifin, 2017). Terdapat banyak hal yang mempengaruhi respon investor dalam pasar modal, beberapa diantaranya yaitu growth opportunity dan leverage.

Growth opportunity merupakan peluang pertumbuhan perusahaan di masa mendatang. Peluang pertumbuhan akan meningkatkan harapan laba di masa mendatang sehingga mempengaruhi ERC dari perusahaan. Pertumbuhan perusahaan dapat dicerminkan dari perubahan aset perusahaan. Informasi positif mengenai perusahaan akan meningkatkan nilai perusahaan yang menyebabkan ERC meningkat. Namun informasi negatif mengenai perusahaan dapat menurunkan nilai perusahaan sehingga ERC menurun. Hasil penelitian Hasanzade et al. (2013), Suardana \& Dharmadiaksa, (2018), dan Henny (2017) menyatakan bahwa growth opportunity berpengaruh secara positif dan signifikan pada ERC. Sedangkan Syariffuloh \& Wahyudin, (2016) dan Arif (2016) menyatakan bahwa growth opportunity berpengaruh negatif pada ERC. Struktur permodalan perusahaan bersumber dari hutang jangka panjang dan modal stakeholder. Leverage memperlihatkan seberapa besar perusahaan bergantung pada permodalan yang berasal dari utang dalam membiayai kegiatan operasinya. Semakin tinggi leverage perusahaan akan menyebabkan berkurangnya respon pasar. Hasil penelitian Rahayu \& Suaryana (2015), Suardana \& Dharmadiaksa (2018), Dewi \& Putra (2017), Henny (2017), serta Hasanzade et al., (2013) menyatakan bahwa leverage berpengaruh negatif terhadap ERC. Namun penelitian Kurniawati (2014), Assagaf et al. (2019) dan Ambarwati \& Sudarmaji (2019) menyatakan bahwa leverage berpengaruh positif terhadap ERC.

Lokasi penelitian yang dipilih dalam penelitian ini adalah perusahaan sektor manufaktur yang terdapat di Bursa Efek Indonesia pada periode 20162018. Perusahaan manufaktur dipilih sebagai sampel dikarenakan perusahaan manufaktur memiliki jumlah perusahaan terbesar jika dibandingkan dengan perusahaan sektor lainnya sehingga dapat merepresentasikan lebih banyak data dalam penelitian. Selain itu perusahaan sektor manufaktur dipilih karena umumnya investor lebih tertarik melakukan investasi pada perusahaan sektor manufaktur di Bursa Efek Indonesia. 
Teori sinyal menyatakan tindakan yang diambil perusahaan dapat memberikan petunjuk bagi investor untuk melihat prospek perusahaan di masa depan. Faradilla et al. (2017) menyatakan penilaian pasar terhadap kemungkinan pertumbuhan perusahaan terlihat dari harga saham yang terbentuk dari nilai ekspektasi terhadap manfaat masa depan yang akan diperoleh. Perusahaan dengan pertumbuhan yang tinggi akan direspon lebih besar oleh investor. Hal ini dikarenakan perusahaan yang memiliki peluang pertumbuhan yang tinggi akan memberi manfaat yang lebih besar di masa mendatang bagi investor. Hasil penelitian Hasanzade et al., (2013), Suardana \& Dharmadiaksa (2018), Arifin (2017), dan Henny, (2017) menyatakan bahwa growth opportunity berpengaruh positif dan signifikan pada ERC. Sedangkan hasil berbeda diperoleh Syariffuloh \& Wahyudin (2016), Kim et al., (2002), dan Arif (2016) yang menyatakan bahwa growth opportunity berpengaruh negatif pada ERC.

$\mathrm{H}_{1}$ : Growth Opportunity berpengaruh positif pada Earning Response Coefficient.

Perusahaan menggunakan utang dalam operasionalnya memiliki tujuan untuk melakukan peningkatan serta pengembangan dalam berproduksi sehingga dapat meningkatkan laba yang dihasilkan perusahaan. Sehingga semakin besar laba yang dihasilkan perusahaan akan meningkatkan return yang diterima oleh para investor sehingga meningkatkan harga saham. Namun reaksi harga saham terhadap unexpected earning yang didapat dipengaruhi oleh risiko pertanggungjawaban perusahaan. Hal ini dikarenakan leverage menentukan mekanisme dalam alokasi penggunaan laba dalam unexpected earning (Moradi et al., 2010). Kurangnya respon investor dalam melakukan investasi karena tingginya tingkat leverage akan berakibat menurunnya ERC pada perusahaan. Hasil penelitian Rahayu \& Suaryana (2015), Suardana \& Dharmadiaksa, (2018), Dewi \& Putra (2017), Henny (2017), Arifin (2017), Moradi et al. (2010), dan Hasanzade et al. (2013), menyatakan bahwa leverage berpengaruh negatif terhadap ERC. Namun penelitian Kurniawati (2014), Assagaf et al. (2019), dan Ambarwati \& Sudarmaji (2019) menyatakan bahwa leverage berpengaruh positif terhadap ERC.

$\mathrm{H}_{2}$ : Leverage berpengaruh negatif pada Earning Response Coefficient.

\section{METODE PENELITIAN}

Penelitian ini menggunakan pendekatan kuantitatif yang berbentuk asosiatif kausal. Penelitian ini dilakukan di perusahaan sektor manufaktur yang terdaftar di Bursa Efek Indonesia (BEI) dengan mengakses situs www.idx.co.id serta mengunduh data sekunder berupa laporan keuangan perusahaan-perusahan manufaktur periode 2016-2018. Objek dalam penelitian ini adalah earning response coefficient (ERC). Sedangkan variabel independen dalam penelitian ini adalah growth opportunity dan leverage.

Growth opportunity diketahui dengan melihat pertumbuhan total aktiva yang dihitung dengan total aktiva periode sekarang dikurangi total aktiva tahun periode sebelumnya, serta dibagi total aktiva periode sebelumnya:

Growth opportunity $=\frac{\text { Total } \text { Aset }_{t}-\text { Total }_{\text {Aset }} \text { t-1 }}{\text { Total } \text { Aset }}$ 
Persamaan yang digunakan untuk menentukan leverage dalam penelitian ini adalah Rasio DER seperti pada penelitian Dewi \& Yadnyana, (2019) dan (Arif, 2016):

$$
\text { DER }=\frac{\text { Total } \text { Utang }}{\text { Total Ekwitas }}
$$

CAR adalah proksi harga saham yang memperlihatkan besarnya respon pasar pada informasi akuntansi yang dipublikasikan perusahaan serta dihitung menggunakan model pasar yang disesuaikan. Data Cummulative Abnormal Return diperoleh dengan beberapa tahapan, diantaranya:

$$
\begin{aligned}
& \mathrm{R}_{i t}=\frac{P_{i t}-P_{i t}-1}{P_{i t}-1} \ldots . . . . . . \\
& \mathrm{R}_{\mathrm{mt}}=\frac{I H S G_{\mathrm{t}}-I H S \mathrm{G}_{\mathrm{t}-1}}{I H S G_{\mathrm{t}-1}} .
\end{aligned}
$$

Keterangan:

$\mathrm{R}_{\mathrm{it}} \quad=$ Return saham perusahaan $\mathrm{i}$ pada periode hari ke $\mathrm{t}$

$\mathrm{P}_{\mathrm{it}} \quad=$ Harga penutupan saham perusahaan $\mathrm{i}$ pada hari ke $\mathrm{t}$

$\mathrm{P}_{\mathrm{it}-1} \quad=$ Harga penutupan saham perusahaan $\mathrm{i}$ pada hari sebelum $\mathrm{t}(\mathrm{t}-1)$

$\mathrm{R}_{\mathrm{mt}} \quad=$ Return pasar perusahaan i pada periode hari ke $\mathrm{t}$

IHSG $_{t}=$ Indeks Harga Saham Gabungan pada hari ke $t$

IHSG $_{\mathrm{t}-1}=$ Indeks Harga Saham Gabungan pada hari $\mathrm{t}-1$

$$
\mathrm{R}_{\mathrm{it}}=\mathrm{R}_{\mathrm{it}}-\mathrm{R}_{\mathrm{mt}} \text {. }
$$

Keterangan:

$\mathrm{AR}_{\mathrm{it}}=$ Abnormal return untuk perusahaan i pada hari ke $\mathrm{t}$

$\mathrm{R}_{\mathrm{it}} \quad=$ Return saham perusahaan i pada hari ke $\mathrm{t}$

$\mathrm{R}_{\mathrm{mt}} \quad=$ Return pasar perusahaan i pada hari ke $\mathrm{t}$

$$
\mathrm{CAR}_{\mathrm{it}}=\mathrm{CAR}_{(-\mathrm{t}, \mathrm{t})}=\sum_{\mathrm{t}-\mathrm{t}} \mathrm{AR}_{\mathrm{it}} \text {. }
$$

Keterangan:

$\mathrm{CAR}_{(-t, t)}=$ Return saham perusahaan i pada hari ke $\mathrm{t}$

$\mathrm{AR}_{\mathrm{it}} \quad=$ Return pasar perusahaan i pada hari ke $\mathrm{t}$

UE merupakan perbedaan antara laba sesungguhnya dengan laba yang diharapkan oleh pasar. UE dihitung menggunakan model seperti dilakukan oleh Collins dan Kothari (1989) dalam Suaryana (2007).

$$
\mathrm{UE}_{\mathrm{it}}=\frac{A E_{\text {it }}-A E_{\text {it }}-1}{A E_{\text {it }-1}}
$$

Keterangan:

$\mathrm{UE}_{\mathrm{it}} \quad$ = Laba non ekspektasian perusahaan i pada periode $\mathrm{t}$

$\mathrm{AE}_{\text {it }}=$ Laba akuntansi setelah pajak perusahaan i pada periode $\mathrm{t}$

$\mathrm{AE}_{\mathrm{it}-1}=$ Laba akuntansi setelah pajak perusahaan i pada tahun $\mathrm{t}-1$

ERC adalah koefisien yang didapat melalui regresi antara proksi harga saham serta laba akuntansi (Dewi, 2015). ERC dihitung dengan persamaan regresi atas data tiap perusahaan sebagai berikut.

$\mathrm{CAR}_{\mathrm{it}}=\mathrm{a}_{0}+\mathrm{a}_{1} \mathrm{UE}_{\mathrm{it}}+\varepsilon$

Keterangan:

$\mathrm{CAR}_{\mathrm{it}}=$ Cummulative abnormal return dari akumulasi AR pada interval dari hari $\mathrm{t}-$

3 hingga hari $\mathrm{t}+3$

$\mathrm{a}_{0} \quad=$ Konstanta

$\mathrm{a}_{1} \quad=$ Earning Response Coefficient

$\mathrm{UE}_{\mathrm{it}}=$ Unexpected earning perusahaan $\mathrm{i}$ pada periode $\mathrm{t}$ 
$=$ Standar error

ERC diestimasi dengan pendekatan firm specific coefficient methodology (FSCM) dengan menggunakan data laporan keuangan berdasarkan kurun waktu tahunan. Persamaan yang digunakan sesuai dengan Suwadjono (1997) dikutip dalam Suaryana (2007).

$\mathrm{CAR}_{\mathrm{j}[1, \mathrm{t}, \mathrm{r}] \mathrm{r}}=\gamma_{0}+\gamma_{1} \mathrm{UE}_{\mathrm{r}}+\varepsilon_{\mathrm{r}}$

Penelitian ini menggunakan data sekunder yang berupa laporan keuangan perusahaan sektor manufaktur yang terdapat di Bursa Efek Indonesia periode 2016-2018, serta data harga saham perusahaan yang diakses melalui website $w w w . i d x . c o . i d$ dan www.id.investing.com. Sampel dari penelitian ini merupakan bagian dari perusahaan sektor manufaktur yang terdaftar di Bursa Efek Indonesia (BEI) periode 2016-2018 yang memenuhi kriteria purposive. Metode pengumpulan data yang digunakan dalam penelitian ini adalah dengan metode observasi non-partisipan.

Teknik analisis regresi yang digunakan dalam penelitian ini adalah analisis regresi linier berganda. Analisis regresi linier berganda merupakan suatu metode permodelan hubungan diantara variabel dependen dengan satu atau lebih variabel independen, yang digunakan dalam menghitung besar pengaruh variabel $X$ dan $Y$ menggunakan koefisien regresi.

$$
Y=\alpha+\beta_{1} X_{1}+\beta_{2} X_{2}+\varepsilon
$$

Keterangan:

$$
\begin{array}{ll}
\mathrm{Y} & =\text { Earning Response Coefficient } \\
\mathrm{X}_{1} & =\text { Growth Opportunity } \\
\mathrm{X}_{2} & =\text { Leverage } \\
\mathrm{a} & =\text { Konstanta } \\
\beta_{1}-\beta_{2} & =\text { Koefisien regresi } \\
\varepsilon & =\text { Error term }
\end{array}
$$

\begin{tabular}{|c|c|c|}
\hline No. & Kriteria & Jumlah \\
\hline 1. & Perusahaan manufaktur yang terdaftar di Bursa Efek Indonesia & 181 \\
\hline 2. & $\begin{array}{l}\text { Perusahaan manufaktur yang tidak terdaftar secara konsisten } \\
\text { selama } 3 \text { tahun periode pengamatan } 2016-2018\end{array}$ & $(43)$ \\
\hline 3. & $\begin{array}{l}\text { Perusahaan manufaktur yang tidak menerbitkan laporan } \\
\text { keuangan tahunan dan tidak memilikitanggal publikasi laporan } \\
\text { keuangan tahunan }\end{array}$ & (21) \\
\hline 4. & $\begin{array}{l}\text { Perusahan manufaktur yang tidak memiliki data lengkap } \\
\text { mengenai harga saham harian dan IHSG di sekitar tanggal } \\
\text { publikasi laporan keuangan }\end{array}$ & $(25)$ \\
\hline 5. & $\begin{array}{l}\text { Perusahaan manufaktur yang tidak menyajikan laporan } \\
\text { keuangan menggunakan mata uang rupiah }\end{array}$ & (27) \\
\hline & Perusahaan yang memenuhi kriteria sampling & 65 \\
\hline
\end{tabular}

\section{HASIL DAN PEMBAHASAN}

Populasi dalam penelitian ini merupakan perusahaan manufaktur yang terdaftar di Bursa Efek Indonesia dengan total sampel yang diperoleh adalah sebanyak 65 perusahaan. Jumlah tersebut diperoleh melalui pengurangan total populasi perusahaan manufaktur dengan sampel yang tidak memenuhi kriteria.

\section{Tabel 2. Penentuan Sampel Penelitian}

Sumber: Data Penelitian, 2019 
Hasil uji statistik deskriptif menjelaskan mengenai nilai minimum, maksimum, rata-rata (mean), dan deviasi standar dalam masing-masing variabel penelitian. Tabel 3 memperlihatkan hasil statistik deskriptif.

Tabel 3. Hasil Statistik Deskriptif

\begin{tabular}{|c|c|c|c|c|c|}
\hline & $\mathrm{N}$ & Minimum & Maksimum & Mean & $\begin{array}{l}\text { Std. } \\
\text { Deviasi }\end{array}$ \\
\hline $\begin{array}{l}\text { Growth } \\
\text { Opportunity }\end{array}$ & 65 & $-0,170$ & 1,130 & 0,090 & 0,170 \\
\hline Leverage & 65 & 0,140 & 10,780 & 1,385 & 1,999 \\
\hline $\begin{array}{l}\text { ERC } \\
\text { Valid N }\end{array}$ & $\begin{array}{l}65 \\
65\end{array}$ & $-0,680$ & 0,900 & $-0,044$ & 0,217 \\
\hline $\begin{array}{l}\text { Growth } \\
\text { Opportunity }\end{array}$ & 65 & & & & \\
\hline
\end{tabular}

Sumber: Data Penelitian, 2019

Variabel growth opportunity dengan total sampel sebanyak 65 memiliki nilai minimum sebesar -0,017 pada PT MBTO dan nilai maksimum sebesar 1,130 pada PT MLBI. Nilai rata-rata (mean) dari variabel growth opportunity adalah sebesar 0,090 dimana nilai tersebut mendekati nilai minimum yang memiliki arti bahwa tingkat peluang pertumbuhan perusahaan manufaktur yang menjadi sampel dalam penelitian ini masih rendah. Nilai standar deviasi sebesar 0,170 memperlihatkan bahwa terjadi penyimpangan nilai growth opportunity terhadap nilai rata-ratanya sebesar 0,170 .

Variabel leverage memiliki nilai minimum sebesar 0,140 pada PT ULTJ dan nilai maksimum sebesar 10,780 pada PT BAJA. Nilai rata-rata (mean) dari variabel leverage adalah sebesar 1,385 dimana nilai tersebut mendekati nilai minimum yang memiliki arti tingkat utang yang dimiliki perusahan manufaktur yang menjadi sampel dalam penelitian ini masih rendah. Nilai standar deviasi sebesar 1,999 memperlihatkan bahwa terjadi penyimpangan nilai leverage terhadap nilai rata-ratanya sebesar 1,999.

Variabel ERC memiliki nilai minimum sebesar $-0,680$ pada PT INAI dan nilai maksimum sebesar 0,900 pada PT TSPC. Nilai rata-rata (mean) dari variabel ERC adalah sebesar -0,044 dimana nilai tersebut mendekati nilai minimum yang memiliki arti tingkat keresponan laba pada perusahaan manufaktur yang menjadi sampel penelitian ini masih rendah. Nilai standar deviasi sebesar 0,217 memperlihatkan bahwa terjadi penyimpangan nilai ERC terhadap nilai rataratanya sebesar 0,217 .

Tabel 4. Hasil Uji Asumsi Klasik

\begin{tabular}{lccccc}
\hline Keterangan & Uji & Uji & \multicolumn{2}{c}{ Uji } & Uji \\
& Normalitas & Autokorelasi & Multikoloniearitas & Heteroskedastisitas \\
\cline { 2 - 6 } & Sig. & Sig. & Tolerance & VIF & Sig. \\
\hline $\begin{array}{l}\text { Growth } \\
\text { Opportunity }\end{array}$ & 0,944 & 0,533 & 0,995 & 1,005 & 0,143 \\
Leverage & & & & & \\
\hline Severay & & & 0,995 & 1,005 & 0,194 \\
\hline
\end{tabular}

Sumber: Data Penelitian, 2019

Sebelum melakukan uji analisis regresi linier berganda, telah dilakukan uji asumsi klasik terlebih dahulu. Uji asumsi klasik dalam penelitian ini terdiri dari uji normalitas, uji autokorelasi, uji multikoloniearitas dan uji heteroskedastisitas. 
Uji asumsi klasik yang dilakukan dalam penelitian ini seluruhya dinyatakan lolos sehingga data dapat disimpulkan terdistribusi normal.

Hasil analisis regresi linier berganda dalam penelitian ini dapat dilihat pada Tabel 4 serta diperoleh model persamaan linier berganda sebagai berikut.

$$
\mathrm{Y}=-2,149+0,406 \mathrm{X} 1-0,552 \mathrm{X} 2+\varepsilon
$$

Tabel 5. Hasil Uji Analisis Regresi Linier Berganda

\begin{tabular}{|c|c|c|c|c|c|}
\hline \multirow[t]{2}{*}{ Model } & \multicolumn{2}{|c|}{ Unstandardized Coefficient } & $\begin{array}{l}\text { Standardized } \\
\text { Coefficient }\end{array}$ & $\overline{\mathrm{T}}$ & Sig \\
\hline & $B$ & Std. Error & Beta & & \\
\hline (Constant) & $-2,149$ & 0,542 & & $-3,963$ & 0,000 \\
\hline $\begin{array}{l}\text { Growth } \\
\text { Opportunity }\end{array}$ & 0,406 & 0,184 & 0,254 & 2,208 & 0,031 \\
\hline Leverage & $-0,552$ & 0,175 & $-0,363$ & $-3,154$ & 0,002 \\
\hline
\end{tabular}

Sumber: Data Penelitian, 2019

Nilai konstanta ( $a$ ) sebesar -2,149 mengandung arti jika nilai variabel bebas yaitu growth opportunity (X1) dan leverage (X2) dianggap konstan atau sama dengan nol, maka nilai ERC (Y) akan turun sebesar 2,149 satuan.

Koefisien regresi variabel growth opportunity (X1) adalah 0,406. Hal ini berarti apabila variabel growth opportunity meningkat, maka akan mengakibatkan peningkatan terhadap ERC sebesar 0,406 satuan dengan asumsi variabel bebas lainnya dianggap konstan.

Koefisien regresi variabel leverage (X2) adalah $-0,552$. Hal ini berarti apabila variabel leverage meningkat, maka akan mengakibatkan penurunan terhadap ERC sebesar 0,552 satuan dengan asumsi variabel bebas lainnya konstan.

Tabel 6. Uji Koefisien Determinasi dan Kelayakan Model

\begin{tabular}{llll}
\hline Model & F & Sig. & Adjusted R square \\
\hline 1 & 6,936 & 0,002 & 0,156 \\
\hline
\end{tabular}

Sumber: Data Penelitian, 2019

Nilai Adjusted $\mathrm{R}^{2}$ adalah 0,156. Hasil ini menunjukkan bahwa pengaruh variabel growth opportunity dan leverage berpengaruh sebesar 15,6 persen pada ERC di perusahaan manufaktur yang terdaftar di Bursa Efek Indonesia tahun 2016-2018, sedangkan sisanya yaitu 84,4 persen dipengaruhi oleh faktor - faktor lain diluar model penelitian.

Nilai signifikansi $F=0,002<a=0,05$. Hal ini berarti model yang digunakan dalam penelitian ini adalah layak digunakan sebagai alat analisis atau dengan kata lain variabel dependen mampu menjelaskan variabel independen.

Hipotesis pertama $\left(\mathrm{H}_{1}\right)$ dalam penelitian ini menyatakan bahwa growth opportunity berpengaruh positif pada ERC. Berdasarkan hasil perhitungan pada Tabel 4.8 terlihat bahwa nilai signifikansi variabel growth opportunity adalah $\mathrm{t}=$ $0,031<\alpha=0,05$ dan nilai koefisien regresi sebesar 0,406 . Jadi H1 diterima, hal ini menunjukkan bahwa growth opportunity berpengaruh positif pada ERC. Hasil penelitian ini sejalan dengan penelitian yang dilakukan oleh Hasanzade et al., (2013), Suardana \& Dharmadiaksa (2018), Faradilla et al. (2017) dan Henny (2017). Semakin pesat peluang pertumbuhan yang dimiliki oleh perusahan, maka akan direspon dengan baik oleh investor sebagai tanda "good news".

Hipotesis kedua $\left(\mathrm{H}_{2}\right)$ dalam penelitian ini menyatakan bahwa leverage berpengaruh negatif pada ERC. Berdasarkan hasil perhitungan pada Tabel 6 
terlihat bahwa nilai signifikansi variabel leverage adalah $\mathrm{t}=0,002<\mathrm{a}=0,05$ dan nilai koefisien regresi sebesar $-0,552$. Jadi $\mathrm{H}_{2}$ diterima, hal ini menunjukkan bahwa leverage berpengaruh negatif pada ERC. Hasil penelitian ini sejalan dengan penelitian yang dilakukan oleh Rahayu \& Suaryana (2015), Suardana \& Dharmadiaksa (2018), Dewi \& Putra (2017), Moradi et al. (2010) dan Henny (2017) yang memperoleh bukti bahwa leverage berpengaruh negatif terhadap ERC. Penggunaan hutang dalam perusahaan dapat meningkatkan profitabilitas perusahaan apabila digunakan pada proporsi yang sesuai untuk memperoleh laba yang lebih tinggi.

Penelitian ini memperkuat bukti terdapatnya teori sinyal dalam menjelaskan bagaimana investor merespon secara berbeda setiap adanya informasi laba yang dipublikasi oleh perusahaan. Hasil penelitian ini menyatakan bahwa growth opportunity berpengaruh positif terhadap nilai ERC pada suatu perusahaan. Tingginya growth opportunity pada perusahaan manufaktur akan meningkatkan nilai ERC dalam perusahaan. Hal ini dikarenakan peluang pertumbuhan perusahaan yang baik akan meningkatkan prospek perusahaan kedepannya sehingga kemungkinan perusahaan memperoleh laba akan tinggi. Sedangkan tingginya nilai leverage dalam perusahaan manufaktur akan menyebabkan rendahnya nilai ERC. Tingkat leverage yang tinggi memperlihatkan bahwa perusahaan menggunakan sebagian besar hutang dalam menjalankan usahanya sehingga memperbesar risiko investor dalam berinvestasi, serta laba akan dialokasikan lebih besar untuk membayar hutang.

\section{SIMPULAN}

Growth opportunity berpengaruh positif pada ERC. Semakin tinggi growth opportunity perusahaan akan meningkatkan harga saham perusahaan dikarenakan prospek perusahaan dalam menghasilkan laba di masa depan semakin tinggi, sehingga ERC perusahaan meningkat.

Leverage berpengaruh negatif pada ERC. Tingginya tingkat leverage dalam perusahaan akan berakibat pada rendahnya respon investor dalam pengumuman informasi laba. Investor cenderung kurang percaya dalam menjalankan investasi pada perusahaan karena risiko tingkat kebangkrutan perusahaan yang lebih tinggi.

Penelitian selanjutnya disarankan untuk melakukan penelitian terhadap ERC dengan menggunakan data laporan keuangan kuartal sehingga dapat merepresentasi lebih banyak data dan time series, menambah variabel bebas lainnya dalam penelitian, serta mmeperluas lingkup penelitian.

\section{REFERENSI}

Al-Baidhani, A. M., Abdullah, A., Ariff, M., Cheng, F. F., \& Karbhari, Y. (2017). Review of earnings response coefficient studies. Corporate Ownership $\mathcal{E}$ Control, 14(3), 299-308. https://doi.org/10.22495/cocv14i3c2art4

Ambarwati, S., \& Sudarmaji, E. (2019). Earning Response Coefficient: The Indonesia Stock Exchange Case. Research Gate, 1-18.

Arif, R. N. (2016). Faktor-Faktor yang Mempengaruhi Earnings Response Coefficient (ERC) pada Perusahaan yang Terdaftar di Bursa Efek Indonesia 
(Periode 2011-2015). Institutional Repository UIN Syarif Hidayatullah.

Arifin, L. (2017). Earning on Response Coefficient in Automobile and Go Public Companies. Journal of Economic and Business, 2(2), 215-238.

Assagaf, A., Murwaningsari, E., Gunawan, J., \& Mayangsari, S. (2019). Factors Affecting the Earning Response Coefficient with Real Activities Earning Management as Moderator: Evidence from Indonesia Stock Exchange. Asian Joumal of Economics, Business and Accounting, 11(2), 1-14. https://doi.org/10.9734/ajeba/2019/v11i230124

Ball, R., \& Brown, P. (1968). An Empirical Evaluation of Accounting Income Numbers. Journal of Accounting Research.

Dechow, P., Ge, W., \& Schrand, C. (2010). Understanding earnings quality: A review of the proxies, their determinants and their consequences. Journal of Accounting and Economics, 50(2-3), 344-401. https://doi.org/10.1016/j.jacceco.2010.09.001

Dewi, A. A. P. K., \& Putra, I. M. P. D. (2017). Pengaruh Leverage dan Ukuran Perusahaan pada Earnings Response Coefficient. E-Jurnal Akuntansi Universitas Udayana, 19(1), 367-391.

Dewi, D. M. (2015). The Role of CSRD on Company's Financial Performance and Earnings Response Coefficient (ERC). Procedia - Social and Behavioral Sciences, 211(September), 541-549. https://doi.org/10.1016/j.sbspro.2015.11.072

Dewi, N. S., \& Yadnyana, I. K. (2019). Pengaruh Profitabilitas dan Leverage pada Earning Response Coefficient dengan Ukuran Perusahan Sebagai Variabel Pemoderasi. E-Jurnal Akuntansi Universitas Udayana, 26(3), 2041-2069.

Faradilla, N. C., Shodiq, N., \& Junaidi. (2017). Pengaruh Persistensi Laba, Growth Opportunities, dan Ukuran Perusahaan Terhadap Relevansi Nilai Laba Akuntansi (Studi Empiris Pada Perusahaan Manufaktur Yang Terdaftar Di BEI Selama Periode 2013-2015). Jurnal Ilmiah Riset Akuntansi, 6(3), 121-134. Hasanzade, M., Darabi, R., \& Mahfoozi, G. (2013). Factors Affecting the Earnings Response Coefficient: An Empirical study for Iran. European Online Journal of Natural and Social Sciences, 2(3), 2551-2560. Retrieved from www.europeanscience.com

Hejazi, R., Ansari, Z., Sarikhani, M., \& Ebrahimi, F. (2012). The Impact Of Earnings Quality And Income Smoothing On The Performance Of Companies Listed In Tehran Stock Exchange. International Journal of Business and Social Science, 2(17), 193-197. Retrieved from http://search.proquest.com/docview/904522920?accountid $=12528 \% 5 \mathrm{Cnhtt}$ $\mathrm{p}: / /$ monash-

dc05.hosted.exlibrisgroup.com/openurl/MUA/MUL_SERVICES_PAGE?ur 1_ver $=$ Z39.88-

2004\&rft_val_fmt=info:ofi/fmt:kev:mtx:journal\&genre=article\&sid=ProQ:Pr oQ:abiglobal\&atitle=The+Impact+

Henny. (2017). Pengaruh Public Ownership dan Growth Opportunity terhadap Leverage dan Future Earnings. Jurnal Muara Ilmu Ekonomi Dan Bisnis, 1(1), 135-144.

Homan, H. S. (2018). The Effect of Corporate Social Responsibility Disclosure to Earnings Response Coefficient. International Journal of Business, Economic and Law, 16(1), 1-8. 
Kim, Y. H., Willett, R. J., \& Jang, J. I. (2002). Default Risk as a Factor affecting the Earnings Response Coefficient. SSRN Electronic Journal, 1-36. https://doi.org/10.2139/ssrn.300350

Kurniawati, A. D. (2014). Pengaruh Karakteristik Perusahaan Terhadap Earnings Response Coefficient. Jurnal Akuntansi Bisnis, XIII(25), 1-24.

Li, H. (2014). Top Executives' Ability and Earnings Quality : Evidence from the Chinese Capital Markets. International Journal of Financial Research, 5(2), 79 86. https://doi.org/10.5430/ijfr.v5n2p79

Maharani, A. A. I. (2014). Respon Pasar Atas Informasi Laba (Replikasi Ball dan Brown 1968). E-Jurnal Akuntansi Universitas Udayana, 8(1), 83-93.

Mashayekhi, B., \& Aghel, Z. L. (2016). A Study on the Determinants of Earnings Response Coefficient in an Emerging Market. International Journal of Ecoomics and Management Engineering, 10(7), 2479-2482.

Moradi, M., Salehi, M., \& Erfanian, Z. (2010). A Study of the Effect of Financial Leverage on Earnings Response Coefficient through out Income Approach : Iranian Evidence. International Review of Accounting, Banking and Finance, 2(2), 103-115.

Radchobeh, zeynab ramzi, Biyabani, S., \& Nikoumaram, H. (2012). Evaluation on the Relation between Earning Response Coefficient (ERC) and Financial Leverage. Journal of Life Science and Biomedicine, 3(1), 83-87.

Rahayu, L. P. A. K., \& Suaryana, I. G. N. A. (2015). Pengaruh Ukuran Perusahaan dan Risiko Gagal Bayar pada Koefisien Respon Laba. E-Jurnal Akuntansi, 13(2), 665-684.

Suardana, K. A., \& Dharmadiaksa, I. B. (2018). Earnings Response Coefficient ANALSISFAKTOR-FAKTOR YANG MEMPENGARUHINYA. Jurnal Riset Akuntansi, JUARA, 8(2), 1-10.

Suaryana, A. (2007). Pengaruh Komite Audit terhadap Kualitas Laba. Jurnal Ilmiah Akuntansi Dan Bisnis, 2(1), 1-22.

Suaryana, A. (2008). Pengaruh Konservatisme Laba terhadap Koefisien Respons Laba. E-Jurnal Akuntansi Universitas Udayana, 1-20.

Syariffuloh, R., \& Wahyudin, A. (2016). Determinan Koefisien Respon Laba. Accounting Analysis Journal, 5(1), 1-9. 